\title{
THE POTENTIAL OF SUBCULTURE Helicoverpa armigera NUCLEAR POLYHEDROSIS VIRUS (HaNPV) TO BE UTILIZED AS AN ALTERNATE SYNTHETIC INSECTICIDES TO CONTROL INSECTS PESTS IN CABBAGES PLANTATION (Brassica oleracea var. capitata $L$ )
}

\author{
Mia Miranti*, Wawan Hermawan, Melanie, Rahman Perdana Hadi, Dicky Budi Sugiarto, \\ and Desy Efriyani Anggraeny Nasution \\ Department of Biology, Faculty of Mathematics and Natural sciences, University of Padjadjaran \\ JI. Raya Bandung Sumedang Km 21 Jatinangor Sumedang \\ ${ }^{*}$ Correspondence author : miantariksa@gmail.com
}

\begin{abstract}
Subculture Helicoverpa armigera Nuclear Polyhedrosis Virus (HaNPV) is an entomopathogenic viruses isolated from cadaver of Helicoverpa armigera larvae, and was succesfully produced in Spodoptera litura larvae as an alternate host. These viral agent have been applied to control the population of three species insects pests Spodoptera litura, Crocidolomia pavonana and Plutella xyllostella which were infested in Cabbages Plantation. The concentration of virus of $4 \times 10^{7}$ Polyhedral $/ \mathrm{ml}$ was sprayed in cabbage leaves 24 hours before infested of larval and every four days after. The research used randomized design which consisted of factor (three species of second instar larvae, S. litura, C. pavonana, P. xyllostella) and eight replications. The result showed that the three species of larval were sensitive against subculture HaNPV infection. The mortality of each larval species (S. litura, C. pavonana and P. xyllostella) were $100 \%, 97.5 \%$ and $98.7 \%$. Subculture HaNPV can be utilized to control the population of three spesies of insects pests in Cabbage Plantation.
\end{abstract}

Key words : Subculture HaNPV, Polyhedral

\section{INTRODUCTION}

Helicoverpa armigera nuclear polihedrosis virus (HaNPV) is a specific entomophatogenic virus isolated from cadaver of Helicoverpa armigera larvae (Teakle, 1994). HaNPV infected several species of insect pests from lepidopteran as Helicoverpa zea, Spodoptera litura, Spodoptera exigua, and Crocidolomia pavonana. These insect pests are found in vegetable plants (Miranti, et. al., 2007). The result of this research showed that HaNPV had a relative wide host range and had a potential to be used as a microbial agent to control the population of insect pests in vegetable cultivation.

HaNPV is effective to control the population of insect pests in vegetable plantation and environtment-friendly for it has a specific host target and has not infected non target host. The most important advantage of using HaNPV as a microbial agent to control the population of insect pests is that it does not leave a dangerous residues in vegetables for human consumption.

A mere problem of utilisation of HaNPV as a microbial agent is a limited capacity of its production for commercial uses. In Indonesia, providing medium and building a specific laboratorium for in vitro production of hanpv in cell cultures is very expensive. Alternatively, in vivo production can be conducted because it is easier and cheaper means of production. However, in vivo production in the main host of $\operatorname{HaNPV}(H$. armigera larvae) faces a problem of strong cannibalism behavior of $H$. armigera larvae itself. 
To solve the problem of HaNPV production for commercial use, in vivo production of HaNPV has been conducted in an alternate host ( $S$. litura larvae). S. litura is used as the alternate host because it is sensitive to HaNPV infection, bigger than $\mathrm{H}$. armigera larval (Miranti, 2008) and results in a higher amount of production of polyhedral virus (Miranti and Wardono, 2009).

Several researches showed that an apropriate alternate host for specific virus production must be able to provide materials in order to enable a perfect virus replication. Research done by Miranti (2008) indicated that HaNPV hosted in S. litura larvae can produce virus polyhedral. Sudhakar and Mathavan (1999) viewed that polyhedral virus which can form polyhedral in an alternate host means that such virus is able to perfectly replicated.

Miranti (2008) has found $\mathrm{HaNPV}_{1}$ (subculture HaNPV), an in vivo production HaNPV in the alternate host. $\mathrm{HaNPV}_{1}$ has been successfully passed a laboratory test to infect $S$. litura and $H$. armigera larvae. In this research, $\mathrm{HaNPV}_{1}$ will be used as an microbial agent to control the population of $S$. litura, C. pavonana and $P$. xyllostella larvae which are infested in cabbage plantation of limited area. These larval were choosen because they frequently damage cabbages and sensitive to HaNPV.

This research suggests that $\mathrm{HaNPV}_{1}$ can be utilised as a environmental-friendly microbial agent to controll population of several insect pests, particularly in vegetable crop.

\section{MATERIALS AND METHODS}

The methods used in this research is experimental method with randomized block design with one factor (spesies of tested second instars larval (S)) consisted of :

$\mathrm{s}_{1}=\mathrm{S}$. litura larvae

$\mathrm{s}_{2}=$ C. pavonana larvae

$\mathrm{s}_{3}=$ P. xyllostella larvae

Each treatment was taken 8 replication with total amounts of sample were 24 . The second instar larval from each species (10 larval) infested on 10 weeks old cabbage crop. The total amount of each larval species used for the experiment were 80 individual, respectively. The concentration of virus suspension was $4 \times 10^{7}$ polyhedra $\mathrm{ml}^{-1}$. The mortality of larval in 20 days observation was a parameter of the experiment.

Data processing with ANOVA, when it is significants that continue by Duncan test (in $5 \%$ ).

\section{Virus stock preparation}

The HaNPV 1 was prepared by propagating the HaNPV in Spodoptera litura and isolated after only 1 passage. S. litura third instars infected with $4 \times 10^{5}$ polyhedral $\mathrm{ml}^{-1}$ virus suspension concentration. The cadaver of infected larval collected in glass container was stored at $4{ }^{\circ} \mathrm{C}$. Then, the cadaver of 40 larval was crush by mortar and mixed with $20 \mathrm{ml}$ triss buffer ( $1 \mathrm{mM}, \mathrm{pH} 7.6$ ) solution and $20 \mathrm{ml} 0,1 \%$ sodium dodecyl sulphat (SDS) solution. This concentrate was stored at $4^{\circ} \mathrm{C}$ for 24 hours.

After storage, the concentrate of virus filtered with two layer of muslin. The suspension of virus was centrifuged ( $3500 \mathrm{rpm}, 15 \mathrm{~min}$ ) at $4^{\circ} \mathrm{C}$. the first supernatant fraction was threw. The pellet was resuspended in $5 \mathrm{ml}$ triss buffer $(1 \mathrm{mM}, \mathrm{pH} 7.6)$ solution and $5 \mathrm{ml} 0.1 \%$ sodium dodecyl sulphat (SDS) solution and it was continued centrifuged (3500rpm, $15 \mathrm{~min}$ ) at $4{ }^{\circ} \mathrm{C}$. 
The washing step for purifying virus treatment were three times replication. The last pellet of the washing step was resuspended with mixed triss buffer $(1 \mathrm{mM}, \mathrm{pH} 7.6)$ solution and $0.1 \%$ sodium dodecyl sulphat (SDS) solution which adding $0.2 \%$ Natrium Azida.

To count the number of polyhedra of virus, $0.1 \mathrm{ml}$ of resuspended virus pellet was mixed by adding $0.9 \mathrm{ml}$ mixed solution of triss buffer $(1 \mathrm{mM}, \mathrm{pH} 7.6)$ and $0.1 \%$ sodium dodecyl sulphat (SDS) with $1: 1$ ratio. The polyhedral number in stock virus suspension were counted using a Neubauer haemocytometer, using a light microscope (magnification 400x). The presence of polyhedra in the suspension was cuboidal shape and green colour dispersed.

The concentration of virus suspension sprayed in the cabbage plants was $4 \times 10^{7}$ polyhedral $\mathrm{ml}^{-1}$ solution.

\section{The larval insect}

The larva insects have been taken from result from rearing in a laboratorium obtained from Vegetables Research Center (Balai Penelitian Sayuran) in Lembang, West Java. Each species of larval storage in plastic container (1000 ml volume), covering with tulle on top container. The larval is feeding with free synthetic insecticide cabbage leaves. The species of larval used for the experiment were second instar larval.

\section{The cabbage plant}

The six weeks cabbage (Brassica oleracea var. capitata $L$ ) plant have been taken from Lembang. The cabbage planted in soil from Lembang mixed with manure fertilizer in $5 \mathrm{~kg}$ volume of polibag. Each cabbace covered by tulle to protect it from another insect pests and cultivation in arboretum area in University of Padjadjaran.

After 10 weeks old cabbage plant, the virus suspension sprayed on the leaves of cabbage at $17.00-18.00$. In 24 hour after, second instars of each larval species infested (10 individual/ each plant) on cabbage leaves. Then, the cabbage plant covered by tulle to prevent run off larvae from the plant. Mortality of larval observation conducted in 20 days or until larval not found in the cabbage plant.

Suspension of virus with concentration $4 \times 10^{7}$ polihedra $\mathrm{ml}^{-1}$ sprayed with hand sprayer (500 $\mathrm{ml}$ volume) every four days in 20 days observation.

\section{RESULT AND DISCUSSION}

The data analysis of effectivity of the HaNPV 1 suspension sprayed to S. litura, $C$. pavonana and $P$. xyllostella were infested in cabbage plant shows in Table 1.

Tabel 1. The data analysis of mortality of each larval species with ANOVA which infested in cabbage plant and sprayed with virus suspension in $4 \times 10^{7}$ polyhedra $\mathrm{ml}^{-1}$ concentration.

\begin{tabular}{llllll}
\hline $\begin{array}{l}\text { Sumber } \\
\text { keragaman }\end{array}$ & $\begin{array}{l}\text { Derajat bebas Jumlah } \\
(\mathrm{db})\end{array}$ & $\begin{array}{l}\text { Kuadrat } \\
\text { kuadrat }(\mathrm{jk})\end{array}$ & $\begin{array}{l}\text { F hitung } \\
\text { tengah }(\mathrm{kt})\end{array}$ & $\mathrm{F}$ table(5\%) \\
\hline Perlakuan & 2 & 0,250 & 0,125 & $1,105 \mathrm{~ns}$ & 3,47 \\
Galat & 21 & 2,375 & 0,1131 & & \\
Umum & 23 & 2,625 & & & \\
\hline
\end{tabular}

ns $=$ not significants in $5 \%$ 
In table 1 the analisys of anova shows that mortality of each species of larval is not significant. The species of larval indicated that the larval sensitive to virus infection. HaNPV (subculture HaNPV) which produced in alternate host tends the stability of virus virulence. The virus still effective to infect S. litura, C. pavonana dan P. xylostella larval as HaNPV (subcultur only in main host $H$. armigera larval). It means that $H_{a N P V}$ effective to protect cabbage plant cultivation in land from limited insect pests (only S. litura, $C$. pavonana and $P$. xylostella).

The number of larval mortality for each spesies of larval in this experiment are shown in Figure 1.

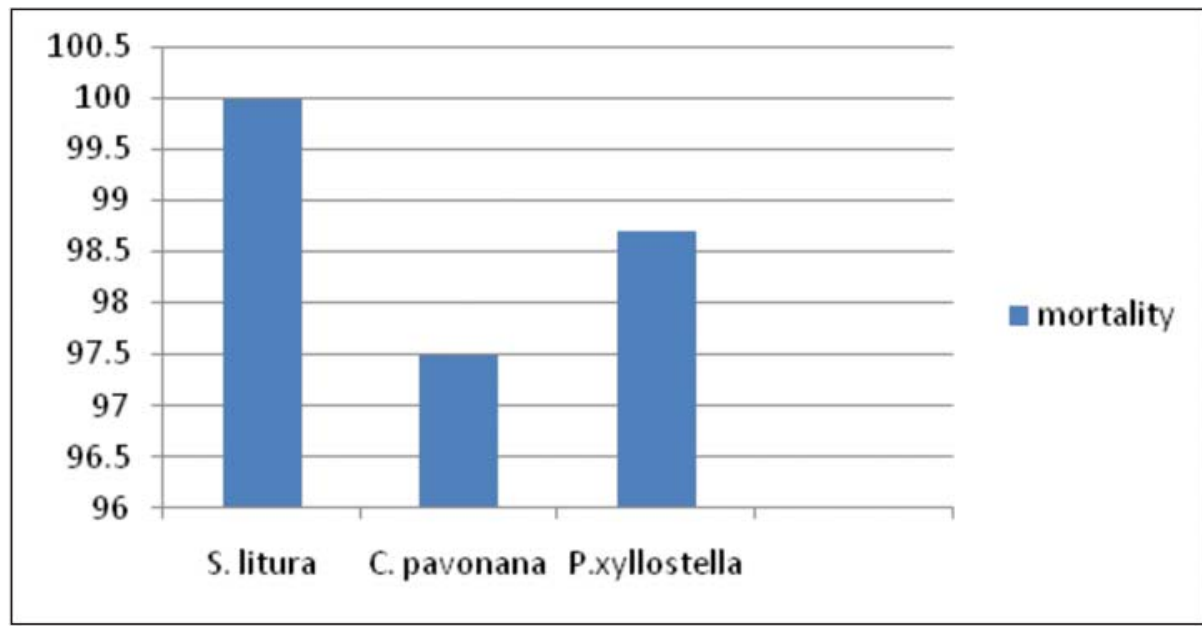

Figure 1. The number of the mortality of each larval species infested in cabbage plants and it sprayed by $\mathrm{HaNPV}_{1}$ suspension with $4 \times 10^{7}$ polihedra $\mathrm{ml}^{-1}$ concentration in 20 days observation.

In figure 1 shows that effectivity of $\mathrm{HaNPV}_{1}$ to infect each larval species caused mortality to S. litura, C. pavonana and P. xyllostella with the values of $100 \%, 97,5 \%$ and $98,7 \%$. This experiment indicated that $\mathrm{HaNPV}_{1}$ can be aplicated directly to control the population of larval which it infested in cabbage plants.

In this research, the values of the mortality was in larval stadium. The imago of each spesies of insect did not found. It means that the application of $\mathrm{HaNPV}_{1}$ to control the population of insect pest larval. The larval infected by virus could be growth to imago stadium. The level of mortality rate (up to $100 \%$ ), shows that the insect pest larval is sensitive against viral infection.

The higher values of mortality tends that $\mathrm{HaNPV}_{1}$ effective used as a microbial agent to control the population of several insect pest especially in cabbage cultivation. Christian, (1994), shows that the high values of mortality indicated that the virus can be replaced syntetic insecticide in plant cultivation. HaNPV is a member of Baculovirus which a group of virus exclusively occluded in proteinaceous crystals. The polyhedra is resistant to environtment effect (Maramorosch and Sherman, 1985). This makes baculoviruses very suitable for the selective control of pest insects (Groner, 1986 in van Lier, 1991).

The experiment shows that HaNPV subculture in alternate host does not lead to the reduction of HaNPV pathogenicity to Spodoptera litura, Crocidolomia pavonana and Plutella xyllostella. HaNPV ${ }_{1}$ still effective to use for protect the cabbage plant from several insect 
pests. $H a N P V_{1}$ tends to increase the mortality of larval infested in cabbage plant cultivation. However, $\mathrm{HaNPV}_{1}$ can be recommended as a microbial agent to replace synthetic insecticide in cabbage cultivation.

\section{CONCLUSIONS}

The use of $\mathrm{HaNPV}_{1}$ as a microbial agent to control the population of several spesies of insect pest as S. litura, C. pavonana and P. xyllostella was effective. HaNPV can be replaced a syntetic insecticide to protect the cabbage plant in agriculture area.

\section{ACKNOWLEDGEMENT}

The authors thank Dr. Wardono Niloperbowo for technical assistance and private communication for development of this research. This project was funded "Penelitian Strategi Nasional" by the Directorat of Higher Education, Ministry of Education and Culture, Republic of Indonesia, through "Lembaga Penelitian dan Pengabdian Kepada Masyarakat", University of Padjadjaran.

\section{REFERENCES}

Christian, P. 1994. Recombinant Baculovirus Insecticides Catalysts for a Change of Heart. Proceedings of the $1^{\text {st }}$ Brisbane Symposium. Biopesticides : opportunities for Australian Industry. C.J Monsour, S. Reid, and R.E. Teakle (eds.). June, 9-10 1994. Brisbane. 4050.

Maramorosch, K. and K.E. Sherman. 1985. Viral Insecticides for Biological Control. London: Academic Press, INC.

Miranti, M., E. Santosa, R. Setiamihardja, and W. Niloperbowo. 2007. Kajian tentang Patogenisitas Helicoverpa armigera Nuclear Polyhedrosis Virus (HaNPV) pada Beberapa Spesies Serangga. Prosiding Simposium Perhimpunan Entomologi Indonesia Cabang Bandung. Sukamandi, 10-11 April 2007.

Miranti, M. 2008. Produksi Helicoverpa armigera Nuclear Polyhedrosis Virus (HaNPV) secara in vivo pada Inang pengganti. Disertasi. Tidak dipublikasikan.

Miranti, M dan W. Niloperbowo. 2009. Pengaruh Konsentrasi Infeksi Helicoverpa armigera Nuclear Polyhedrosis Virus (HaNPV) pada Tingkat Kematian, Waktu Kematian dan produktivitas Produksi Polihedra dalam Larva Spodoptera litura F. sebagai Inang Pengganti. Jurnal Agrikultura 20. 5-11.

Sudhakar, S., and Mathavan. 1999. Electron Microscopical Studies and Restriction Analysis of Helicoverpa armigera Nucleo Polyhedrosis Virus. Via http://www.iisc.ernet.in/ academy/jbiosci/sept1999/article3

Teakle, R.E. 1994. Virus Control of Heliothis and Other Key Pests : Potential and Use, and the Local Scene. Proceedings of the $1^{\text {st }}$ Brisbane Symposium Biopesticides : Opportunities for Australian Industry. C.J. Monsour, S. Reid, and R.E. Teakle (eds.). June, 9-10 1994. Brisbane. 51-56.

Van Lier, F., J.M. Vlak. And J. Tramper. 1991. Production of Baculovirus-expressed Proteins from Suspension Culture of Insect Cell. In : Spier, R.E. and Griffith, J.B. (eds.) Animal Cell Biotechnology. Vol V. Academic Press, London. 169-188. 